DOI: 10.12731/2658-4034-2020-3-44-47

\title{
ПРОБЛЕМЫ ИСПОЛЬЗОВАНИЯ КОМПЕТЕНТНОСТНОГО ОБУЧЕНИЯ
}

\author{
Преображенский А.П. ${ }^{1}$, Чопоров О.Н.
}

${ }^{1}$ Воронежский институт высоких технологий,

г. Воронеж, Российская Федерация

${ }^{2}$ Воронежский государственный технический университет,

г. Воронеж, Российская Федерация

В данной работе проведено рассмотрение возможностей применения технологий комптентностного обучения. Приведень примеры, на что будут влиять подобные подходы.

Ключевые слова: компетенция; обучающийся; методика; технология.

\section{PROBLEMS OF USE OF COMPETENT EDUCATION}

\section{Preobrazhenskiy A.P. ${ }^{1}$, Choporov O.N. ${ }^{2}$}

${ }^{1}$ Voronezh Institute of High Technologies, Voronezh, Russia ${ }^{2}$ Voronezh State Technical University, Voronezh, Russian Federation

In this paper, we consider the possibilities of applying the technologies of competency-based learning. Examples are given to influence such approaches.

Keywords: competence; student; methodology; technology.

\section{Введение}

Компетентностные подходы активным образом развиваются в течение последнего времени в образовательной сфере. В данной работе обсуждаются возможности и перспективы применения подобных подходов.

\section{О характеристиках компетентностных подходов в образовании}

Применение компетентностно-ориентированных способов можно рассматривать как базис в парадигме действующего обучения. 
Прежде всего, ориентируются на то, что справедливым является применение метода проектов.

Такой подход обсуждался уже достаточно давно, в него вносились различные дополнения, но лишь в последнее десятилетие он уже сформировался весьма полным способом.

Кроме того, исходят теории компетенций из того, что есть самостоятельность обучающихся. Есть у них и обозначенная мера ответственности за свои действия.

Современные дисциплины нельзя рассматривать отдельным образом. Есть такие, которые опираются на результаты изучения других дисциплин.

Но, можно отметить и такие, которые формируются на базе междисциплинарного подхода.

При формировании траекторий индивидуального обучения для обучающихся необходимо стремление к освоению главными составляющими. Тогда можно говорить о том, что на выходе из учебного учреждения будут специалисты высокого класса.

При построении системы образования необходимо понимать, какая модель будет применяться. Выбор модели будет оказывать влияние на те методические подходы, которые будут применяться в дальнейшем [1].

При использовании подхода, базирующегося на компетенциях, важно формировать соответствующие контрольно-измерительные материалы. Сейчас преподаватели имеют возможности включения в них самых разных способов, в том числе - деловые игры (они включают целый спектр развития подкомпетенций), написание письменных работ, использование комплексных заданий. Все в итоге ведет к укреплению как компетентностного, так и знаниевого уровней $[2,3]$.

Значимость внутри контрольных материалов подразделяется на имеющую личностный и социальный характер. Кроме того, играет роль практическая подготовка $[4,5]$.

Это важно, чтобы педагог демонстрировал связь излагаемого материала, с одной стороны - с теми дисциплинами, которые уже были прочитаны, с их теоретической компонентой. 
С другой стороны, изложение должно выглядеть не сухой теорией, а демонстрировать конкретные возможности применения на практике соответствующих разработок.

Нельзя забывать и о том, что обучающиеся должны развиваться как личности. Вузовское обучение оказывает большое влияние на профессиональную ориентацию личностей [3].

Обучающиеся не должны слепо выполнять предоставляемые для них задания. Тогда будет просто формироваться хороший исполнитель.

Важно, чтобы проходило формирование продуктивного мышления, например, среди студентов инженерных специальностей и направлений. Тогда можно говорить о том, что будут развиваться и инженерные качества.

В образовательных организациях должны стремиться к тому, чтобы личности развивать самыми разными способами. В этом помогут соответствующие внеучебные подразделения и кружки.

Необходимо обеспечивать подготовку портфолио будущих выпускников. Оно поможет им в дальнейшем трудоустройстве.

\section{Выводы}

Применение компетентностных подходов предоставляет широкие возможности для подготовки будущих специалистов. Но при этом они будут обуславливать и изменения в самой образовательной системе.

\section{Список литературы}

1. Преображенский Ю.П. О подготовке инженерных кадров // В сборнике: Современные инновации в науке и технике Сборник научных трудов 8-й Всероссийской научно-технической конференции с международным участием. Ответственный редактор А.А. Горохов. 2018. С. $175-179$.

2. Преображенский Ю.П., Преображенская Н.С., Львович И.Я. Некоторые аспекты информатизации образовательных учреждений и развития медиакомпетентности преподавателей и руководителей // Вестник Воронежского государственного технического университета. 2013. Т. 9. № 5-2. С. 134-136. 
3. Преображенский Ю.П. Характеристики информационно-образовательного пространства вуза // В сборнике: Антропоцентрические науки: инновационный взгляд на образование и развитие личности Материалы VII Международной научно-практической конференции. 2018. С. 218-219.

4. Максимова И.В., Ваганова О.И., Карпова М.А. Использование видеофрагментов при преподавании дисциплин естественнонаучного цикла // Современные исследования социальных проблем (электронный научный журнал). 2018. Т. 9. № 9-2. С. 56-59.

5. Якушева С.Д. Самоменеджмент в деятельности педагога современного образовательного комплекса // Современные исследования социальных проблем (электронный научный журнал). 2018. Т. 9. № 11. C. $242-263$.

\section{References}

1. Preobrazhenskij Yu.P. O podgotovke inzhenernyh kadrov // V sbornike: Sovremennye innovacii v nauke i tekhnike Sbornik nauchnyh trudov 8-j Vserossijskoj nauchno-tekhnicheskoj konferencii s mezhdunarodnym uchastiem. Otvetstvennyj redaktor A.A. Gorohov. 2018. S. 175-179.

2. Preobrazhenskij Yu.P., Preobrazhenskaya N.S., L'vovich I.Ya. Nekotorye aspekty informatizacii obrazovatel'nyh uchrezhdenij i razvitiya mediakompetentnosti prepodavatelej i rukovoditelej // Vestnik Voronezhskogo gosudarstvennogo tekhnicheskogo universiteta. 2013. T. 9. № 5-2. S. 134-136.

3. Preobrazhenskij Yu.P. Harakteristiki informacionno-obrazovatel'nogo prostranstva vuza // V sbornike: Antropocentricheskie nauki: innovacionnyj vzglyad na obrazovanie i razvitie lichnosti Materialy VII Mezhdunarodnoj nauchno-prakticheskoj konferencii. 2018. S. 218-219.

4. Maksimova I.V., Vaganova O.I., Karpova M.A. Ispol'zovanie videofragmentov pri prepodavanii disciplin estestvennonauchnogo cikla // Sovremennye issledovaniya social'nyh problem (elektronnyj nauchnyj zhurnal). 2018. T. 9. № 9-2. S. 56-59.

5. Yakusheva S.D. Samomenedzhment $v$ deyatel'nosti pedagoga sovremennogo obrazovatel'nogo kompleksa // Sovremennye issledovaniya social'nyh problem (elektronnyj nauchnyj zhurnal). 2018. T. 9. № 11. S. 242-263. 